BOOK REVIEW

\title{
FREE COUNTRY
}

\section{Sir Sydney Kentridge KCMG, QC, Hart Publishing Oxford 2012 ISBN-10: 1849464677, ISBN-13: 9781849464673 Price $£ 20.00 \mathrm{hb}$}

\author{
The Rt Hon The Lord Scott of Foscote
}

'Free Country' is a collection of lectures and talks, twelve in all, given by Sir Sydney Kentridge QC, over a period running from 1979 to 2011 and now published as a collection. Sir Sydney became in 2009 an honorary LLD of the University of Buckingham, an addition to the seven or eight honorary degrees that he already held from Universities in England, South Africa and elsewhere in the world. Susan Edwards, Professor in Law at the University of Buckingham, asked me to write a review of "Free Country' for inclusion in this year's edition of The Denning Law Journal, published annually by the University. It was an honour and privilege to have received this invitation, my only qualification for which is that besides, like Sir Sydney, having had a career as a lawyer in England, I like him, was educated and brought up in South Africa and, when I came to England, did so on a South African passport. Having read, and re-read, the remarkable collection of lectures and talks that constitutes 'Free Country' I find it impossible to write about the collection without first writing about its very distinguished author.

Sydney Kentridge is a South African born and bred. He was born in Johannesburg in 1922 and educated in that city. He took a law degree at the University of the Witwatersrand ('Wits' in common parlance) and another at Oxford University. After service in the South African forces in World War II he qualified as an advocate in South Africa, the equivalent of a barrister in England, and in 1949 began practice in Johannesburg.

In 1948 the Nationalist party won a majority in the general election in South Africa, defeating by a considerable margin the previous government led by South Africa's great war leader, General Smuts. So, in 1948, Dr Malan, the leader of the Nationalist party, became the Prime Minister and the Nationalists remained in power for over 40 years. Over that period the system of apartheid i.e. strict racial segregation was prescribed, regulated and enforced pursuant to statutes passed by the South African Parliament.

I should make clear that racial segregation was not invented by the Nationalist government. It had been a social feature of the country throughout 


\section{BOOK REVIEW}

the period that the Cape Province and Natal had been British colonies and the Transvaal and the Orange Free State had been independent republics. After the Act of Union in 1910 racial segregation as a social feature remained the norm throughout the country. But the philosophy underling the imposition of the apartheid system required that the racial segregation and white domination that had become features broadly accepted by the bulk of the white population as cultural desiderata should become legal imperatives to be strenuously, sometimes ruthlessly, enforced. Under apartheid, blacks were restricted to certain occupations, restricted as to the ownership of land or where they could live. Miscegenation between individuals of different races became a criminal offence and only whites could vote or run for political office. Asian Indians and persons of mixed race (known in South Africa as 'Cape coloureds') had some, albeit limited, political rights. Africans had none. This was the political and social state of South African when Sydney Kentridge began his professional career as an advocate in Johannesburg.

His career flourished. He became a Senior Counsel ('SC'), the equivalent of a QC or KC, in 1965 and appeared in cases not only in the Transvaal courts but also in the Appellate Division, South Africa's highest court in those days, which sat in Bloemfontein. Many of the cases in which he appeared, and particularly those with a political content or political implications, are referred to in the 'Free Country' collection. Three of his clients were the great Nelson Mandela, who after 27 years of imprisonment on Robben Island became President of South Africa in 1994 and retained that office until his resignation in 1999, Chief Albert Luthuli, leader of the 'Zulus' in Natal, and who became President-General of the African National Congress ('the ANC') in 1952, and Archbishop Desmond Tutu, who instituted and conducted the Truth and Reconciliation Commission after the collapse of the apartheid regime, and the release from prison of Nelson Mandela. Each of these three men was awarded the Nobel Peace prize, Chief Luthuli in 1960, Archbishop Tutu in 1984 and Nelson Mandela in 1998. I am not the first to remark that there has probably been no other advocate who could claim three such internationally distinguished clients. In 1997 Sydney Kentridge left South Africa, came to England, was called to the Bar of England and Wales and began practice in this country as a barrister from chambers at 1 Brick Court in London. A Foreword to 'Free Country' has been written by two former members of the 1 Brick Court Chambers, each of whom was a distinguished barrister and is now a distinguished judge. Sir David Lloyd Jones is currently a Lord Justice of Appeal and Sir George Legatt is currently a High Court Judge sitting in the Queen's Bench Division. Their Foreword constitutes a really excellent introduction to and précis of the 'Free Country' collection. My pleasure in reading it is accentuated by the fact that George Legatt's father, Sir Andrew Legatt was himself a High Court Judge in the Queen's Bench Division and has been a friend of mine for many years. 
Sir Sydney's translation of himself from being a highly regarded advocate practising in South Africa to being a highly regarded barrister practising in London took place after his experience of some 30 years of authoritarian Nationalist rule in South Africa. The events in those years included the Sharpeville massacre of 69 black protestors in March 1960, the 1976 riots when at least 600 people, mostly black, were killed while protesting against the apartheid restrictions on their lives, and the trials and imprisonment of Nelson Mandela. Nelson Mandela had, in 1956, been arrested on treason charges, charges that carried a potential death sentence on conviction. At his trial he was defended by Sydney Kentridge, acquitted on the treason charge, but convicted on other charges, and sentenced in 1962, to five years in prison. In 1964 further charges were laid against him. He was convicted and sentenced to life imprisonment. These events and the depressing future that the continuance in power of the Nationalist Party regime must had seemed to indicate, not only for black South Africans, must have been powerful factors leading Sydney to question his own future as a lawyer in South Africa. And then came the terrible saga of the arrest, the mistreatment while in police custody and subsequent death of Steve Biko. The story was told in the annual Steve Biko Memorial Lecture given by Sydney at the University of Cape Town (my own Alma Mata) on $11^{\text {th }}$ September 2011. This lecture is the eleventh lecture in the 'Free Country' collection. An inquest was held into the death of Steve Biko. He had, after all, died while in police custody. Sydney, with two colleagues, appeared at the inquest on behalf of Steve Biko's widow and his mother. The inquest began on $14^{t}$ November 1977 and lasted two weeks. The verdict was that nobody was to blame for the death. The Steve Biko chapter of 'Free Country' contains a coruscating review of the events that had lead to Steve Biko's death, of the inquest proceedings and of the verdict. It is not difficult to suppose that these must have been matters that cemented Sydney Kentridge's decision to remove himself and his legal talents from South Africa and to transplant them in England. These talents did not, however, post 1977, become confined to England. In October 1978 Sydney gave the Owen J. Roberts Memorial Lecture at the University of Pennsylvania. This is the first lecture in the 'Free Country' collection. He became a member of the Botswana Court of Appeal from 1981 to 1988 and a Judge of the Courts of Appeal of Jersey and Guernsey from 1988 to 1992. And when, following the release of Nelson Mandela from prison, the constitutional reforms in South Africa in 1994 and the collapse of apartheid, the Constitutional Court of South Africa was established as the highest court of the land, Sydney acted as an Acting Justice of that court in 1995 and 1996.

His main legal activity, however post 1977, has been in England. He was awarded Silk and became a QC, in 1984. At that time, the Attorney General was entitled each year to nominate one individual for Silk. I do not know whether or not that practice still continues (I suspect it does not), but in 1984 


\section{BOOK REVIEW}

Sir Michael Havers QC, the then Attorney General nominated Sydney. The nomination was widely acclaimed by the legal professions in England and, I expect, by many others. In 1999 Sydney was knighted (KCMG) for 'services to international law and justice'. At page (v), the first page of the 'Free Country' Foreword, the authors record complimentary remarks made by Lord Alexander of Weedon QC, which included the observation that Sydney 'is simply the most highly regarded advocate in the Commonwealth'.

I shall not attempt to improve on the contents of the Foreword of 'Free Country' as a review and précis of the contents of the collection. I doubt whether I could. The two authors of the Foreword, at page (vi), identify two themes which emerge from the 'Free Country' collection. They identify '...on the one hand an acute sense of the fragility of the rights and values that define a free country; and on the other hand, and at the same time, an intense appreciation of just how much such rights and freedoms which we sometimes take for granted, really matter.' These are perspicacious remarks that are relevant to be born in mind when considering some of the political and legal issues current in this country. Our present government has introduced the possibility of 'closed material procedure' (CMP) in an attempt to assist the obtaining of convictions against individuals charged with committing, or attempting to commit, or conspiring to commit terrorist offences. CMP has the result that certain evidence led by the prosecution in order to obtain a conviction may be withheld from disclosure to the defendant. So a defendant may find himself or herself convicted without knowing what evidence has led to this result and without having had the opportunity to give his or her answer in denial or in explanation of the incriminating evidence. This does not seem consistent with the 'rights and freedoms' which we take for granted.

We take for granted the rule of law which is perhaps the most important bulwark on which the cohesion of a civilised society depends. But the strength and value of the rule of law depend, I suggest, on the respect it commands from those who are subject to it. If an individual does not have access to justice, whether to prosecute his claims against others or to defend himself against claims made against him, or does not have any realistic expectation of a fair trial, how can that individual be expected to have respect for the rule of law? In the South Africa of the apartheid years, on which the 'Free Country' collection is based, how could the blacks have any respect for the rule of law? And if, in this country, an individual finds himself convicted of an offence on the basis of evidence which has not been disclosed to him and which he has had no opportunity to deny or explain, how can the individual have, or retain, respect for the rule of law? The damage to cohesive society that the apartheid regime produced in South Africa may have been remedied or at least mitigated by the collapse of the system and the magnanimity shown by, in particular, Nelson Mandela, but also, no doubt, by many others. But the damage to respect for the rule of law caused by legal procedures or legal 
practices that prevent a fair trial or the perception of a fair trial may have consequences, the nature of which cannot be foretold. The scene that unfolds as the lectures in the 'Free Country' collection are read underlines the importance of maintaining in our own country respect for the rule of law. 'Free Country' is a book that everyone who believes in the rule of law should read. 